\title{
Implementasi Metode Teorema Bayes Untuk Mendiagnosa Penyakit Pada Tumbuhan Bunga Kertas
}

\author{
Abdul Rahman ${ }^{1}$ dan Fricles Ariwisanto Sianturi ${ }^{2}$ \\ ${ }^{1,2}$ Program Studi Teknik Informatika, STMIK Pelita Nusantara \\ Jl. St. Iskandar Muda No. 1 Medan \\ E-mail : abdulrahman070499@gmail.com,
}

\begin{abstract}
Abstrak - Minimnya Keilmuan terhadap penyakit Bunga Kertas serta Keterlambatan penanganan penyakit sering kali dialami para pemilik Bunga Kertas. Oleh sebab itu perlu adanya tindakan/penanganan cepat untuk mencegah terinfeksi penyakit yang lebih serius. Teorema Bayes adalah metode yang digunakan untuk memprediksi probabilitas. Untuk itu dalam penelitian ini akan dilakukan Analisa data penyakit Bunga Kertas menggunakan teorema bayes dengan menggunakan Delapan data penyakit yaitu Jamur Hitam, Belalang Daun, Kutu Akar, Ulat Kantung, Kutu Putih, Kutu Daun, Rayap Batang dan Oksigen Menipis. Berdasarkan uraian tersebut, dibutuhkan sebuah system yang dapat menggantikan seorang Pakar yang memiliki basis keilmuan tentang penyakit Bunga Kertas, yaitu Sebuah Sistem Pakar. Perkembangan teknologi komputer sudah semakin luas dan pesat. Sehingga banyak digunakan di berbagai bidang. Sehingga kali ini Sistem Pakar yang dibangun menggunakan basis Web.

Kata Kunci: Penyakit, Bunga Kertas, Teorema Bayes, Sistem Pakar, Aplikasi Web
\end{abstract}

\begin{abstract}
Lack of knowledge about paper flower diseases and limitations in handling diseases are often experienced by paper flower owners. Therefore, it is necessary to take action / quick treatment to prevent infection with a more serious disease. Bayes theorem is a method used to predict probabilities. For this reason, in this study, a paper flower disease data analysis will be carried out using the Bates theorem using four disease data, namely Black Fungus, Leaf Grasshoppers, Root Lice, Pocket Caterpillars, White Ticks, Aphids, Stem Termites and Oxygen Depletion. Based on this description, we need a system that can represent an expert who has a base of knowledge and experience about paper flower disease, namely an expert system. The development of information technology is increasingly widespread and rapid. So it is widely used in various fields. So this time the Expert System was built using a Web base.
\end{abstract}

Keywords: Disease, Paper Flower, Bayes Theorem, Expert System, Web Application

\section{Pendahuluan}

Perkembangan teknologi pada era modern saat ini sangatlah berkembang pesat dimana teknologi sangat dibutuhkan pada manusia sehingga dapat mempermudah ataupun mempercepat pekerjaan manusia[1]. Dengan adanya teknologi banyak penelitian-penelitian yang dapat dilakukan dengan mudah dan praktis, teknologi juga tak hanya membantu tentang pekerjaan ilmu komputer dimana teknologi juga dapat membantu pekerjaan seorang pakar kedokteran, perbankan, pertambangan, penjualan, akuntasi dan pertanian[2]. Salah satunya adalah pakar pertanian, dimana seorang pakar pertanian dapat mempermudah pekerjaannya dengan melakukan sebuah penelitian dengan bantuan komputer maka dengan adanya perkembangan teknologi saat ini seorang pakar tidak lagi begitu kesulitan untuk melakukan sebuah penelitian[3]. Seorang pakar cukup memindahkan ilmu yang iya dapat kedalam sebuah komputer sehingga kemampuan yang ada pada seorang pakar akan sama persis yang di masukkan kedalam computer[4]. Salah satu penelitian pakar pertanian yang dapat di masukkan kedalam komputer adalah penyakit pada tumbuhan Bunga kertas.

Tumbuhan Bunga Kertas (Bougenville) merupakan tumbuhan yang hidup di Iklim Tropis tumbuhan ini juga merupakan tumbuhan yang termasuk muda dalam menambahkan jumlah populasinya. Namun meskipun tergolong mudah dalam menambah populasinya tumbuhan bunga kertas (bougenville) juga memiliki penyakit yang mudah menyerang, Berbagai Jenis Penyakit pada Tumbuhan Bunga Kertas ini misalnya Jamur Hitam, Ulat Kantong, Kutu Putih, Belalang Daun, Kutu Daun, Oksigen Menipis, Rayap.

Batang, dan Kutu Akar inilah yang sangat berdampak pada kematian pada Bunga Kertas sehingga tingkat keresahan pada petani Bunga Kertas meningkat akibat penyakit yang di alami Bunga tersebut. Seiring dengan perkembangan zaman saat ini perkembangan ilmu teknologi sangatlah cepat dan pesat sehingga mampu untuk membantu pekerjaan manusia dalam mengatasi penyakit pada tumbuhan bunga kertas, Penelitian Kali ini adalah salah satu yang dapat membantu seorang pakar dalam menjalankan sebuah Penelitian Terkait mendiagnosa Penyakit Pada Tumbuhan dan membutuhkan teknologi yang bisa membantu mensukseskan usahanya pada bagian Mendiagnosa Penyakit Pada Tumbuhan. Perkembangan 
ini juga harus dilengkapi dengan perencanaan serta strategi yang tepat agar memperoleh hasil terbaik dalam penelitian ini. Pemilik "Taman Bougenville Albaya Bonsai” Kerap sekali mengeluhkannya tingkat gejala yang timbul pada Tumbuhan Bunga Kertas sehingga mengakibatkannya kematian pada Bunga Kertas tersebut, Hal lain yang memicunya kematian pada Tumbuhan Bunga Kertas karena lambatnya tingkat penanganan untuk mengobati Tumbuhan tersebut karena terbatasnya akses penjualan obat untuk tumbuhan Bunga Kertas, maka dengan ini seorang pakar membutuhkan yang namanya sistem pakar untuk membantu pekerjaannya dalam mendiagnosa penyakit bunga kertas sehingga setiap langkah yang di lakukan tidak lagi salah langkah sebab ada teknologi yang akan membantu permasalahan seorang pakar.

Untuk membantu seorang pakar dalam menangani permasalahan penyakit pada tumbuhan bunga kertas, maka dibutuhkan salah satu cabang dari Ilmu komputer yaitu Sistem Pakar. Sistem Pakar adalah sistem berbasis komputer yang menggunakan pengetahuan, fakta, dan teknik penalaran dalam memecahkan masalah, yang biasanya hanya dapat diselesaikan oleh seorang pakar dalam bidang tertentu. Adapun metode yang digunakan pada penelitian ini adalah Metode Teorema Bayes Digunakan untuk menghitung Probabilitas terjadinya suatu peristiwa berdasarkan pengaruh yang didapat dari hal observasi. Teorema Bayes juga dapat digunakan sebagai alat pengambilan keputusan untuk memperbarui tingkat kepercayaan informasi. Dengan bantuan sistem tersebut diharapkan mampu mengidentifikasi penyakit Bunga Kertas melalui gejalanya disertakan dan memberikan solusi layaknya seorang ahli.

Ada beberapa penelitian yang membahas tentang tumbuhan atau tanaman yang telah dilakukan sebelumnya. Diantaranya adalah penelitian oleh Widians, Puspitasari dan Putri (2020) dengan judul penelitian "Penerapan Teorema Bayes dalam Sistem Pakar Anggrek Hitam”. Hasil dari penelitian tersebut adalah metode Teorema Bayes dalam mendiagnosa penyakit tumbuhan bunga Anggrek Hitam pada sistem pakar dirancang berdasarkan algoritma Teorema Bayes yaitu merupakan cara dari konsep ketidakpastian yang diubah menjadi variable data. Dapat disimpulkan bahwa akurasi sistem pakar menggunakan metode Teorema Bayes berdasarkan penggunaan 21 data diagnosa gejala dan 8 penyakit Tumbuhan Bunga Anggrek Hitam yang telah diuji mempunyai tingkat akurasi keberhasilan yang cukup baik sesuai dengan diagnosa pakar yaitu sebesar 39\%. Penelitian lain oleh Fadillah,Andika dan Saripurna (2020) dengan judul penelitian "Sistem Pakar Mendiagnosa Penyakit dan Hama Penyerang Tanaman Bougenville Dengan metode Teorema Bayes". Hasil dari penelitian tersebut adalah sebuah sistem pakar untuk melakukan diagnosa penyakit Tumbuhan Bougenville beserta nilai probabilitas dari penyakit. Hasil diagnosa yang menunjukkan tingkat kepercayaan sistem terhadap penyakit tersebut dan saran yang harus diberikan. Dapat disimpulkan bahwa akurasi sistem pakar menggunakan metode Teorema Bayes berdasarkan penggunaan 14 data diagnosa gejala dan 4 penyakit Tanaman Bougenville yang telah diuji mempunyai tingkat akurasi keberhasilan yang cukup baik sesuai dengan diagnosa pakar yaitu sebesar 66,66\%, Berdasarkan penelitianpenelitian terdahulu yang sudah dibahas penulis, maka dalam kasus ini penulis menggunakan metode Teorema Bayes dalam Mendiagnosa Penyakit Pada Tumbuhan Bunga Kertas. Penulis memilih metode Teorema Bayes untuk kasus ini karena metode ini memiliki keunggulan dengan perhitungan yang sederhana, serta memilki nilai yang tepat. Metodologi ini mempunyai tingkat selektifitas yang baik karena dapat menentukan Penyakit memalui gejala yang timbul. Dimana seetiap gejala yang timbul berasal sebelum menjadi penyakit.

\section{Tinjauan Pustaka \\ 2.1. Bunga Kertas}

Bougenville atau disebut sebagai "Bunga Kertas" merupakan salah satu jenis tanaman yang banyak kita jumpai di wilayah tropis seperti Indonesia. Bunga kertas sendiri terbilang cukup popoler di indonesia, sering digunakan sebagai aksen penghias tanaman. Bunga ini dinamakan bunga kertas karena memang memiliki kelopak dengan tekstur yang mirip kertas. Dibeberapa daerah banyak orang yang menyebut bunga kertas dengan nama "Bunga Zinnia".Bunga jenis ini merupakan salah satu bunga yang dapat dikatakan mudah untuk dibudidayakan.

Bougenville adalah tanaman hias yang sangat populer dan banyak ditanam dipekarangan rumah, taman kota maupun sebagai penghias di pinggir jalan. Pohon bougenville termasuk berbatang kecil yang sulit tumbuh dengan tegak namun untuk spesies tertentu batangnya bisa sebesar pohon kelapa. Selain dinikmati karena keelokan warna-warni bunganya, Bougenville sebernarnya patut ditanam dipekatangan karena mengandung berbagai manfaat herbal. Daun, Bunga, Akar dan kulit batang Bougenville mengandung sapoin dan polifenol. Bougenville tidak hanya dapat menjadi tanaman hias, tetapi juga dapat berguna sebagai obat untuk mencegah berbagai jenis penyakit seperti hepatitis, penyakit bisul, obat keputihan, haid tidak teratur, dan lain sebagainya. (Fadilla,Andika dan Saripurna, 2020)

Beberapa jenis penyakit Bunga kertas yang sering diderita (Fadilla,Andika dan Saripurna, 2020): 
1. Layu Bakteri

2. Ulat Kantung

3. Kutu Putih

4. Layu Fusarium

\subsection{Sistem Pakar}

Sistem pakar (Expert System) adalah sistem yang berbasis komputer yang menggunakan pengetahuan, fakta, dan teknik penalaran dalam memecahkan masalah yang biasanya hanya dapat dipecahkan oleh seorang pakar dalam bidang tersebut[5]. Pada dasarnya sistem pakar diterapkan untuk mendukung aktivitas pemecahan masalah, beberapa aktivitas pemecahan yang dimaksud antara lain: pembuatan keputusan (decision making), pemanduan pengetahuan (Knowledge fusing), prakiraan (forecasting), pengaturan (regulation), pengendalian (controlling), diagnosis (diagnosing), perumusan (prescribing), penjelasan (explaining), pemberian nasihat (advising), dan pelatihan (tutoring). Selain itu sistem pakar juga dapat berfungsi sebagai asisten yang pandai dari seorang pakar(Kusrini 2018:11)

\subsection{Metode Teorema Bayes}

Teorema Bayes dikemukakan oleh Thomas Bayes (inggris) pada tahu 1763 dan kemudian disempurnakan oleh laplace[6]. Teorema Bayes digunakan untuk menghitung probabilitas terjadinya suatu peristiwa berdasarkan pengaruh yang didapat dari hal observasi. (Azmi dan Yasin, 2020:59-60)

\section{Dimana:}

$$
P(H \mid E)=\frac{P(E \mid H) \cdot P(H)}{P(E)}
$$

- $\mathrm{P}(\mathrm{H} \mid \mathrm{E})$ : probabilitas hipotesis $\mathrm{H}$ jika di berikan evidence $\mathrm{E}$

- $\mathrm{P}(\mathrm{E} \mid \mathrm{H})$ : probabilitas munculnya evidence $\mathrm{E}$ jika diketahui hipotesis $\mathrm{H}$

- $\mathrm{P}(\mathrm{H})$ : probabilitas hipotesis H tanpa memandang evidence apapun

- $\mathrm{P}(\mathrm{E})$ : probabilitas evidence $\mathrm{E}$

\section{Hasil Dan Pembahasan}

\subsection{Analisa Data}

Pada bagian ini akan dijelaskan secara umum bagaimana cara menentukan hasil dari diagnosa penyakit Bunga Kertas berdasarkan data dan hasil penilaian perhitungan dengan menggunakan metode teorema bayes.

Tabel 1. Penyakit Bunga Kertas
\begin{tabular}{|c|l|c|}
\hline $\begin{array}{c}\text { Kode } \\
\text { Penyakit }\end{array}$ & \multicolumn{1}{|c|}{$\begin{array}{c}\text { Nama Penyakit Bunga } \\
\text { Kertas }\end{array}$} & Bobot \\
\hline P001 & Jamur Hitam & 1,5 \\
\hline P002 & Ulat Kantung & 1,3 \\
\hline P003 & Kutu Putih & 1,5 \\
\hline P004 & Belalang Daun & 1,1 \\
\hline P005 & Kutu Daun & 1,6 \\
\hline P006 & Oksigen Menipis & 1,6 \\
\hline P007 & Rayap Batang & 1,4 \\
\hline P008 & Kutu Akar & 1,6 \\
\hline
\end{tabular}

Tabel 2. Kode Gejala penyakit dan Bobot 


\begin{tabular}{|c|c|c|}
\hline Kode & Gejala Penyakit & Bobot \\
\hline G001 & $\begin{array}{l}\text { Pembusukan pada bagian } \\
\text { pucuk tanaman }\end{array}$ & 0,5 \\
\hline G002 & $\begin{array}{l}\text { Tulang daun berubah } \\
\text { warna kekuningan }\end{array}$ & 0,3 \\
\hline G003 & $\begin{array}{l}\text { Terdapat Pembusukan } \\
\text { pada cabang }\end{array}$ & 0,5 \\
\hline G004 & $\begin{array}{l}\text { Adanya pembusukan di } \\
\text { daun }\end{array}$ & 0,2 \\
\hline G005 & Daun membusuk di ujung & 0,5 \\
\hline G006 & $\begin{array}{l}\text { Terdapat berecak hitam di } \\
\text { daun }\end{array}$ & 0,2 \\
\hline G007 & Terdapat lubang di daun & 0,3 \\
\hline G008 & $\begin{array}{l}\text { Daun menggulung dan } \\
\text { keriting }\end{array}$ & 0,3 \\
\hline G009 & $\begin{array}{l}\text { Terdapat bintik-bintik } \\
\text { putih di belakang daun }\end{array}$ & 0,5 \\
\hline G010 & $\begin{array}{l}\text { Terdapat bintik-bintik } \\
\text { putih dibatang }\end{array}$ & 0,5 \\
\hline G011 & $\begin{array}{l}\text { Terdapat bintik-bintik } \\
\text { putih di akar tanaman }\end{array}$ & 0,5 \\
\hline G012 & $\begin{array}{l}\text { Terdapat patah pada } \\
\text { ranting-ranting muda }\end{array}$ & 0,4 \\
\hline G013 & Daun muda terkikis habis & 0,5 \\
\hline G014 & $\begin{array}{l}\text { Terdapat warna } \\
\text { kecoklatan pada ujung } \\
\text { daun }\end{array}$ & 0,2 \\
\hline G015 & Daun Tua Mengkeriting & 0,6 \\
\hline G016 & Daun Mudah Rontok & 0,5 \\
\hline G017 & Tulang Daun mudah layu & 0,5 \\
\hline G018 & Daun muda menguning & 0,5 \\
\hline G019 & Baja terlalu banyak & 0,7 \\
\hline G020 & Media Tanah terlalu padat & 0,4 \\
\hline G021 & Batang tua keropos & 0,4 \\
\hline G022 & Akar mulai habis & 0,7 \\
\hline G023 & Batang mudah lapuk & 0,3 \\
\hline
\end{tabular}




\begin{tabular}{|c|l|c|}
\hline Kode & \multicolumn{1}{|c|}{ Gejala Penyakit } & Bobot \\
\hline G024 & Tumbuhan menjadi kurus & 0,5 \\
\hline G025 & Tumbuhan menjadi kerdil & 0,3 \\
\hline G026 & layu & 0,8 \\
\hline
\end{tabular}

\subsection{Rule Sistem Pakar Mendiagnosa Penyakit Bunga Kertas}

Tabel 3. Fakta dan Aturan Gejala Penyakit

\begin{tabular}{|c|l|}
\hline No. Rule & \multicolumn{1}{|c|}{ Aturan Gejala dan Penyakit } \\
\hline R001 & $\begin{array}{l}\text { JIKA Pembusukan pada bagian pucuk tanaman DAN Tulang daun berubah warna kekuningan DAN } \\
\text { Terdapat pembusukan pada cabang DAN Adanaya pembusukan di daun MAKA Jamur Hitam }\end{array}$ \\
\hline R002 & $\begin{array}{l}\text { JIKA Daun membusuk di ujung DAN Terdapat bercak hitam di daun DAN Terdapat lubang di Daun } \\
\text { DAN Daun menggulung dan keriting MAKA Ulat Kantung. }\end{array}$ \\
\hline R003 & $\begin{array}{l}\text { JIKA Terdapat bintik-bintik putih dibelakang daun DAN Terdapat bintik-bintik putih dibatang DAN } \\
\text { Terdapat bintik-bintik putih di akar tanaman MAKA Kutu Putih. }\end{array}$ \\
\hline R004 & $\begin{array}{l}\text { JIKA Terdapat patah pada ranting-ranting muda DAN Daun muda terkikis habis DAN Terdapat } \\
\text { warna kecoklatan pada ujung daun MAKA Belalang Daun }\end{array}$ \\
\hline R005 & $\begin{array}{l}\text { JIKA Daun Tua mengkriting Dan Daun Mudah Rontok DAN Tulang Daun mudah layu MAKA } \\
\text { Kutu Daun. }\end{array}$ \\
\hline R006 & $\begin{array}{l}\text { JIKA Daun muda Menguning DAN Baja terlalu banyak DAN Media tanah terlalu pada MAKA } \\
\text { Oksigen Menipis }\end{array}$ \\
\hline R007 & JIKA Batang Tua keropos DAN Akar mulai habis DAN Batang mudah lapuk MAKA Rayap Batang \\
\hline R008 & $\begin{array}{l}\text { JIKA Tumbuhan menjadi Kurus DAN Tumbuhan menjadi Kerdil DAN Daun menjadi Kecil dan } \\
\text { Layu Maka Kutu Akar. }\end{array}$ \\
\hline
\end{tabular}

\subsection{Analisis Metode}

Metode yang digunakan penulis agar kebutuhan pengguna dapat dipenuhi yaitu dengan menggunakan metode teorema bayes. Metode teorema bayes merupakan salah satu cara untuk mengatasi ketidakpastian data yang dibangun dari teori probabilistik.

\subsection{Studi Kasus}

1. Jamur Hitm (P001)

a. Gejala dan bobot untuk penyakit ini adalah sebagai berikut:

$$
\begin{aligned}
& \mathrm{G} 001=0,5\left(\mathrm{E} \mid \mathrm{H}_{1}\right) \\
& \mathrm{G} 002=0,3\left(\mathrm{E} \mid \mathrm{H}_{2}\right) \\
& \mathrm{G} 003=0,5\left(\mathrm{E} \mid \mathrm{H}_{3}\right) \\
& \mathrm{G} 004=0,5\left(\mathrm{E} \mid \mathrm{H}_{4}\right)
\end{aligned}
$$

b. Menentukan Nilai semesta dari penjumlahan hipotesa diatas

$$
\begin{aligned}
\sum_{i=1}^{12} & =G 1+G 2+G 3+G 4 \\
& =05+0,3+0,5+0,2=1
\end{aligned}
$$

c. Untuk menghitung nilai semesta berdasaarkan gejala yang timbu pada penyakit bunga kertas

$$
\begin{aligned}
& P(H 1)=\frac{H 1 * \sum_{k=1}^{12}}{H 1 * \sum_{k=1}^{12}}=\frac{0,5 * 1,5}{0,5 * 1,5}= \\
& P(H 2)=\frac{H 2 * \sum_{k=1}^{12}}{H 2 * \sum_{k=1}^{12}}=\frac{0,3 * 1,5}{0,3 * 1,5}= \\
& P(H 3)=\frac{H 3 * \sum_{k=1}^{12}}{H 3 * \sum_{k=1}^{12}}=\frac{0,5 * 1,5}{0,5 * 1,5}=
\end{aligned}
$$

d. Menghitung nilai probabilitas $\mathrm{H}$ tanpa memandang evidence apapun dan Menentukan hasil $\mathrm{P}\left(\mathrm{H}_{i} \mid \mathrm{E}\right)$ atau probabilitas hipotesis $\mathrm{H}_{\mathrm{i}}$ benar jika diberikan evidence $\mathrm{E}$ 
e. Menjumlahkan seluruh nilai $\mathrm{P}(\mathrm{Hi} \mid \mathrm{E})$

$$
\begin{aligned}
& P(H 1)=\frac{0,5 * 1,5}{0,5 * 1,5}=\frac{0,75}{0,75}=1 \\
& P(H 1)=\frac{0,5 * 1,5}{0,5 * 1,5}=\frac{0,75}{0,75}=1 \\
& P(H 1)=\frac{0,5 * 1,5}{0,5 * 1,5}=\frac{0,75}{0,75}=1
\end{aligned}
$$

$\sum_{i=1}^{12}$ Bayes $=$ bayes $1+$ bayes $2+$ bayes $3=$

$\sum_{i=1}^{12}$ Bayes $=1+1+1=3$

2. Ulat Kantung (P002)

a. Gejala dan bobot untuk penyakit ini adalah sebagai berikut:

$$
\begin{aligned}
& \mathrm{G} 005=0,5\left(\mathrm{E} \mid \mathrm{H}_{1}\right) \\
& \mathrm{G} 006=0,2\left(\mathrm{E} \mid \mathrm{H}_{2}\right) \\
& \mathrm{G} 007=0,3\left(\mathrm{E} \mid \mathrm{H}_{3}\right) \\
& \mathrm{G} 008=0,3\left(\mathrm{E} \mid \mathrm{H}_{4}\right)
\end{aligned}
$$

b. Menentukan Nilai semesta dari penjumlahan hipotesa diatas

$$
\begin{aligned}
\sum_{i=1}^{2} & =G 5+G 6+G 7+G 8 \\
& =05+0,2+0,3+0,3=1,3
\end{aligned}
$$

c. Untuk menghitung nilai semesta berdasaarkan gejala yang timbul pada penyakit bunga kertas $P(H 1)=\frac{H 1 * \sum_{k=1}^{2}}{H 1 * \sum_{k=1}^{2}}=\frac{0,5 * 1,3}{0,5 * 1,3}=$

d. Menghitung nilai probabilitas $\mathrm{H}$ tanpa memandang evidence apapun dan Menentukan hasil $\mathrm{P}\left(\mathrm{H}_{i} \mid \mathrm{E}\right)$ atau probabilitas hipotesis $\mathrm{H}_{\mathrm{i}}$ benar jika diberikan evidence $\mathrm{E}$

e. Menjumlahkan seluruh nilai $\mathrm{P}(\mathrm{Hi} \mid \mathrm{E})$

$$
P(H 1)=\frac{0,5 * 1,3}{0,5 * 1,3}=\frac{0,65}{0,65}=1
$$

$$
\begin{aligned}
& \sum_{i=1}^{2} \text { Bayes }=\text { bayes } 1 \\
& \sum_{i=1}^{2} \text { Bayes }=1
\end{aligned}
$$

3. Kutu Putih (P003)

a. Gejala dan bobot untuk penyakit ini adalah sebagai berikut:

$$
\begin{aligned}
& \mathrm{G} 009=0,5\left(\mathrm{E} \mid \mathrm{H}_{1}\right) \\
& \mathrm{G} 0010=0,5\left(\mathrm{E} \mid \mathrm{H}_{2}\right) \\
& \mathrm{G} 0011=0,5\left(\mathrm{E} \mid \mathrm{H}_{3}\right)
\end{aligned}
$$

b. Menentukan Nilai semesta dari penjumlahan hipotesa diatas

$$
\begin{aligned}
\sum_{i=1}^{3} & =G 9+G 10+G 11 \\
& =05+0,5+0,5=1,5
\end{aligned}
$$

c. Untuk menghitung nilai semesta berdasaarkan gejala yang timbul pada penyakit bunga kertas $P(H 1)=\frac{H 1 * \sum_{k=1}^{3}}{H 1 * \sum_{k=1}^{3}}=\frac{0,5 * 15}{0,5 * 1,5}=$

d. Menghitung nilai probabilitas $\mathrm{H}$ tanpa memandang evidence apapun dan Menentukan hasil $\mathrm{P}\left(\mathrm{H}_{i} \mid \mathrm{E}\right)$ atau probabilitas hipotesis $\mathrm{H}_{\mathrm{i}}$ benar jika diberikan evidence $\mathrm{E}$

$$
P(H 1)=\frac{0,5 * 1,5}{0,5 * 1,5}=\frac{0,75}{0,75}=1
$$

e. Menjumlahkan seluruh nilai $\mathrm{P}(\mathrm{Hi} \mid \mathrm{E})$

$$
\begin{aligned}
& \sum_{i=1}^{3} \text { Bayes }=\text { bayes } 1 \\
& \sum_{i=1}^{3} \text { Bayes }=1
\end{aligned}
$$

4. Belalang Daun (P004)

a. Gejala dan bobot untuk penyakit ini adalah sebagai berikut:

$$
\begin{aligned}
\mathrm{G} 0012 & =0,4\left(\mathrm{E} \mid \mathrm{H}_{1}\right) \\
\mathrm{G} 0013 & =0,5\left(\mathrm{E} \mid \mathrm{H}_{2}\right) \\
\mathrm{G} 0014 & =0,2\left(\mathrm{E} \mid \mathrm{H}_{3}\right)
\end{aligned}
$$

b. Menentukan Nilai semesta dari penjumlahan hipotesa diatas 


$$
\begin{aligned}
\sum_{i=1}^{4} & =G 12+G 13+G 14 \\
& =04+0,5+0,2=1,1
\end{aligned}
$$

c. Untuk menghitung nilai semesta berdasaarkan gejala yang timbul pada penyakit bunga kertas $P(H 1)=\frac{H 1 * \sum_{k=1}^{4}}{H 1 * \sum_{k=1}^{4}}=\frac{0,5 * 1,1}{0,5 * 1,1}=$

d. Menghitung nilai probabilitas $\mathrm{H}$ tanpa memandang evidence apapun dan Menentukan hasil $\mathrm{P}\left(\mathrm{H}_{i} \mid \mathrm{E}\right)$ atau probabilitas hipotesis $\mathrm{H}_{\mathrm{i}}$ benar jika diberikan evidence $\mathrm{E}$

$P(H 1)=\frac{0,5 * 1,1}{0,5 * 1,1}=\frac{0,55}{0,55}=1$

e. Menjumlahkan seluruh nilai $\mathrm{P}(\mathrm{Hi} \mid \mathrm{E})$

$\sum_{i=1}^{4}$ Bayes $=$ bayes 1

$\sum_{i=1}^{4}$ Bayes $=1$

5. Kutu Daun (P005)

a. Gejala dan bobot untuk penyakit ini adalah sebagai berikut:

$$
\mathrm{G} 0015=0,6\left(\mathrm{E} \mid \mathrm{H}_{1}\right)
$$

$\mathrm{G} 0016=0,5\left(\mathrm{E} \mid \mathrm{H}_{2}\right)$

$\mathrm{G} 0017=0,5\left(\mathrm{E} \mid \mathrm{H}_{3}\right)$

b. Menentukan Nilai semesta dari penjumlahan hipotesa diatas

$$
\begin{aligned}
\sum_{i=1}^{5} & =G 15+G 16+G 17 \\
& =06+0,5+0,5=1,6
\end{aligned}
$$

c. Untuk menghitung nilai semesta berdasaarkan gejala yang timbul pada penyakit bunga kertas $P(H 1)=\frac{H 1 * \sum_{k=1}^{5}}{H 1 * \sum_{k=1}^{5}}=\frac{0,5 * 1,6}{0,5 * 1,6}=$

d. Menghitung nilai probabilitas $\mathrm{H}$ tanpa memandang evidence apapun dan Menentukan hasil $\mathrm{P}\left(\mathrm{H}_{i} \mid \mathrm{E}\right)$ atau probabilitas hipotesis $\mathrm{H}_{\mathrm{i}}$ benar jika diberikan evidence $\mathrm{E}$

e. Menjumlahkan seluruh nilai $\mathrm{P}(\mathrm{Hi} \mid \mathrm{E})$

$$
P(H 1)=\frac{0,5 * 1,6}{0,5 * 1,6}=\frac{0,8}{0,8}=1
$$

$$
\begin{aligned}
& \sum_{i=1}^{5} \text { Bayes }=\text { bayes } 1 \\
& \sum_{i=1}^{5} \text { Bayes }=1
\end{aligned}
$$

6. Oksigen menipis (P006)

a. Gejala dan bobot untuk penyakit ini adalah sebagai berikut:

$$
\begin{aligned}
& \mathrm{G} 0018=0,5\left(\mathrm{E} \mid \mathrm{H}_{1}\right) \\
& \mathrm{G} 0019=0,7\left(\mathrm{E} \mid \mathrm{H}_{2}\right) \\
& \mathrm{G} 0020=0,4\left(\mathrm{E} \mid \mathrm{H}_{3}\right)
\end{aligned}
$$

b. Menentukan Nilai semesta dari penjumlahan hipotesa diatas

$$
\begin{aligned}
\sum_{i=1}^{6} & =G 18+G 19+G 20 \\
& =05+0,7+0,4=1,6
\end{aligned}
$$

c. Untuk menghitung nilai semesta berdasaarkan gejala yang timbul pada penyakit bunga kertas $P(H 1)=\frac{H 1 * \sum_{k=1}^{6}}{H 1 * \sum_{k=1}^{6}}=\frac{0,5 * 1,6}{0,5 * 1,6}=$

d. Menghitung nilai probabilitas $\mathrm{H}$ tanpa memandang evidence apapun dan Menentukan hasil $\mathrm{P}\left(\mathrm{H}_{i} \mid \mathrm{E}\right)$ atau probabilitas hipotesis $\mathrm{H}_{\mathrm{i}}$ benar jika diberikan evidence $\mathrm{E}$

$$
P(H 1)=\frac{0,5 * 1,6}{0,5 * 1,6}=\frac{0,8}{0,8}=1
$$

e. Menjumlahkan seluruh nilai $\mathrm{P}(\mathrm{Hi} \mid \mathrm{E})$

$$
\begin{aligned}
& \sum_{i=1}^{6} \text { Bayes }=\text { bayes } 1 \\
& \sum_{i=1}^{6} \text { Bayes }=1
\end{aligned}
$$

7. Rayap Batang (P007)

a. Gejala dan bobot untuk penyakit ini adalah sebagai berikut: 
$\mathrm{G} 0021=0,4\left(\mathrm{E} \mid \mathrm{H}_{1}\right)$

$\mathrm{G} 0022=0,7\left(\mathrm{E} \mid \mathrm{H}_{2}\right)$

$\mathrm{G} 0023=0,3\left(\mathrm{E} \mid \mathrm{H}_{3}\right)$

b. Menentukan Nilai semesta dari penjumlahan hipotesa diatas

$\sum_{i=1}^{6}=G 21+G 22+G 23$

c. Untuk menghitung nilai semesta berdasaarkan gejala yang timbul pada penyakit bunga kertas $P(H 1)=\frac{H 1 * \sum_{k=1}^{7}}{H 1 * \sum_{k=1}^{7}}=\frac{0,4 * 1,4}{0,4 * 1,4}=$

d. Menghitung nilai probabilitas $\mathrm{H}$ tanpa memandang evidence apapun dan Menentukan hasil $\mathrm{P}\left(\mathrm{H}_{i} \mid \mathrm{E}\right)$ atau probabilitas hipotesis $\mathrm{H}_{\mathrm{i}}$ benar jika diberikan evidence $\mathrm{E}$

e. Menjumlahkan seluruh nilai $\mathrm{P}(\mathrm{Hi} \mid \mathrm{E})$

$$
P(H 1)=\frac{0,4 * 1,4}{0,4 * 1,4}=\frac{0,56}{0,56}=1
$$

$$
\begin{aligned}
& \sum_{i=1}^{7} \text { Bayes }=\text { bayes } 1 \\
& \sum_{i=1}^{7} \text { Bayes }=1
\end{aligned}
$$

8. Kutu Akar (P008)

a. Gejala dan bobot untuk penyakit ini adalah sebagai berikut:

$$
\begin{aligned}
& \mathrm{G} 0024=0,5\left(\mathrm{E} \mid \mathrm{H}_{1}\right) \\
& \mathrm{G} 0025=0,3\left(\mathrm{E} \mid \mathrm{H}_{2}\right) \\
& \mathrm{G} 0026=0,8\left(\mathrm{E} \mid \mathrm{H}_{3}\right)
\end{aligned}
$$

b. Menentukan Nilai semesta dari penjumlahan hipotesa diatas

$$
\sum_{i=1}^{6}=G 24+G 25+G 26
$$

c. Untuk menghitung nilai semesta berdasaarkan gejala yang timbul pada penyakit bunga kertas

$$
P(H 1)=\frac{H 1 * \sum_{k=1}^{8}}{H 1 * \sum_{k=1}^{8}}=\frac{0,3 * 1,6}{0,3 * 1,6}=
$$

d. Menghitung nilai probabilitas $\mathrm{H}$ tanpa memandang evidence apapun dan Menentukan hasil $\mathrm{P}\left(\mathrm{H}_{i} \mid \mathrm{E}\right)$ atau probabilitas hipotesis $\mathrm{H}_{\mathrm{i}}$ benar jika diberikan evidence $\mathrm{E}$

e. Menjumlahkan seluruh nilai $\mathrm{P}(\mathrm{Hi} \mid \mathrm{E})$

$$
P(H 1)=\frac{0,3 * 1,6}{0,3 * 1,6}=\frac{0,48}{0,48}=1
$$

$$
\begin{aligned}
& \sum_{i=1}^{8} \text { Bayes }=\text { bayes } 1 \\
& \sum_{i=1}^{8} \text { Bayes }=1
\end{aligned}
$$

Langkah Selanjutnya menghitung hasil dari proses diagnosa yang telah dilakukan

$$
\sum_{i=1}^{1}+\sum_{i=1}^{2}+\sum_{i=1}^{3}+\sum_{i=1}^{4}+\sum_{i=1}^{5}+\sum_{i=1}^{6}+\sum_{i=1}^{7}+\sum_{i=1}^{8}
$$

Atau Hasil $=$ Total bayes $1+$ Total Bayes $2+$ Total Bayes $3+$ Total Bayes $4+$ Total bayes $5+$ Total Bayes

$$
6+\text { Total Bayes } 7+\text { Total Bayes } 8
$$

$$
\begin{aligned}
& =3+1+1+1+1+1+1+1 \\
& =10
\end{aligned}
$$

Maka perhitungan probabilitas penyakitnya adalah :

1. Penyakit Jamur Hitam (P001)

$$
=3 / 10 * 100 \%=30 \%
$$

2. Penyakit Ulat Kantung (P002)

$$
=1 / 10 * 100 \%=10 \%
$$

3. Penyakit Kutu Putih (P003)

$$
=1 / 10 * 100 \%=10 \%
$$

4. Penyakit Belalang Daun (P004) 


$$
=1 / 10 * 100 \%=10 \%
$$

5. Penyakit Kutu Daun (P005)

$$
=1 / 10 * 100 \%=10 \%
$$

6. Penyakit Oksigen menipis (P006)

$$
=1 / 10 * 100 \%=10 \%
$$

7. Penyakit Rayap Batang (P007)

$$
=1 / 10 * 100 \%=10 \%
$$

8. Penyakit Kutu Akar (P008)

$$
=1 / 10 * 100 \%=10 \%
$$

Berdasarkan perhitungan menggunakan metode teorema bayes diatas, maka dapat diketahui bahwa diagnosa penyakit pada tumbuhan bunga kertas adalah Jamur Hitam (P001) dengan nilai keyakinan 30\%. Maka dengan ini dari gejala yang timbul pada bunga kertas penyakit jamur hitam (P001) dinyatakan dengan kurang pasti.

\subsection{Hasil}

Implementasi sistem merupakan tahap menterjemahkan perancangan berdasarkan hasil analisis sistem. Pada tahap implementasi sistem ini diharapkan sistem yang telah dirancang siap untuk dioperasikan pada keadaan yang sebenarnya, sehingga akan diketahui apakah sistem yang dibuat benar-benar dapat menghasilkan tujuan yang diharapkan..

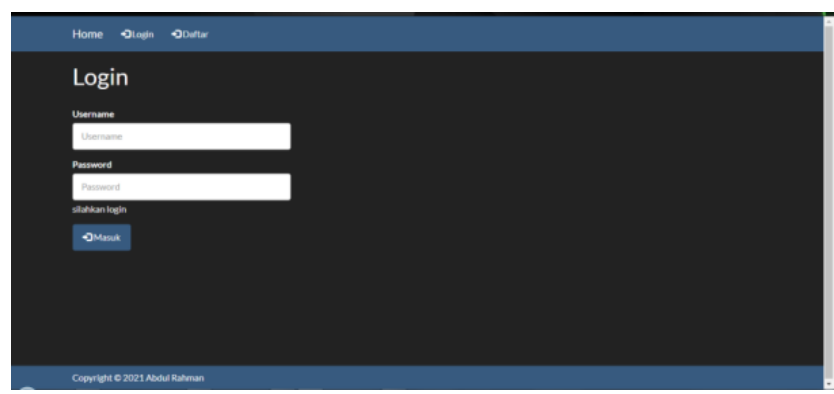

Gambar 1. Interface Form Login

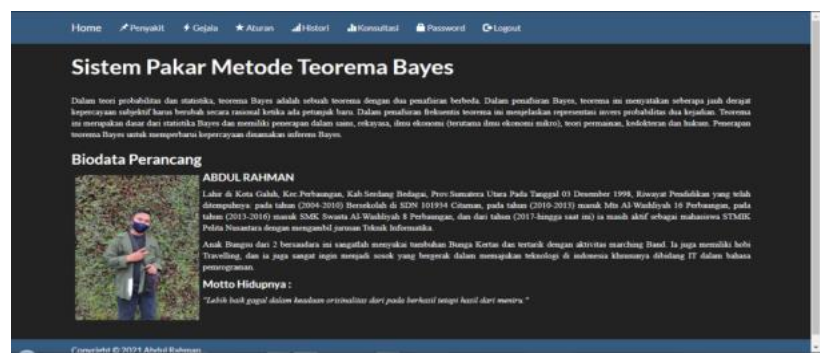

Gambar 2. Interface Form Menu Utama

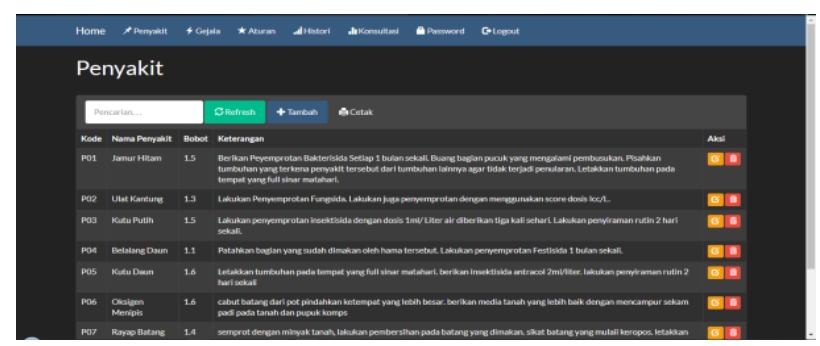

Gambar 3. Interface Form Penyakit 


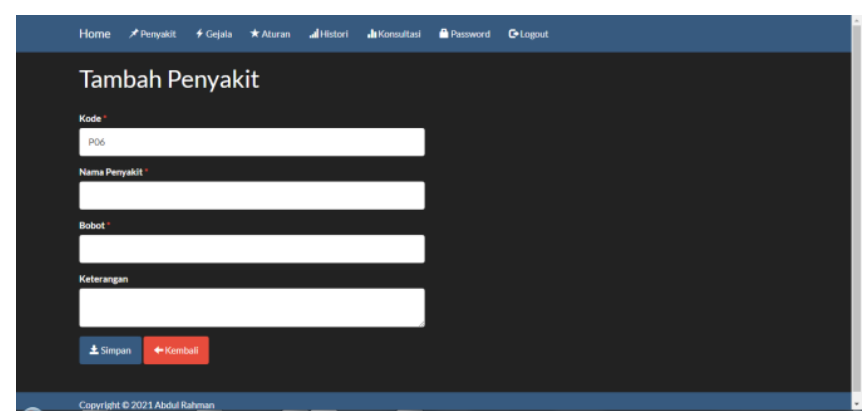

Gambar 4. Interface Form Menu Tambahan Penyakit

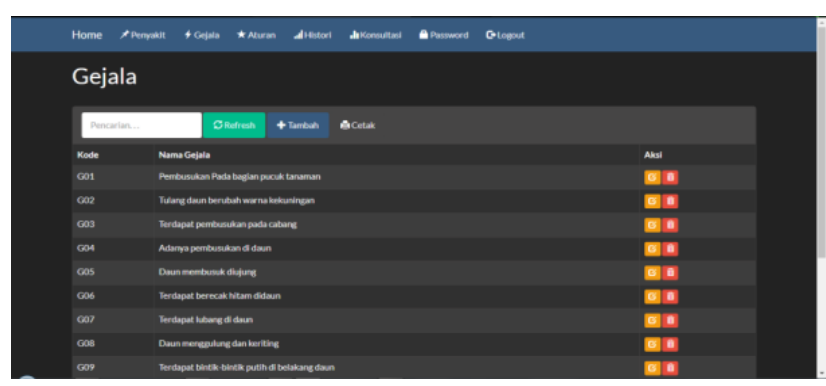

Gambar 5. Interface Form Gejala

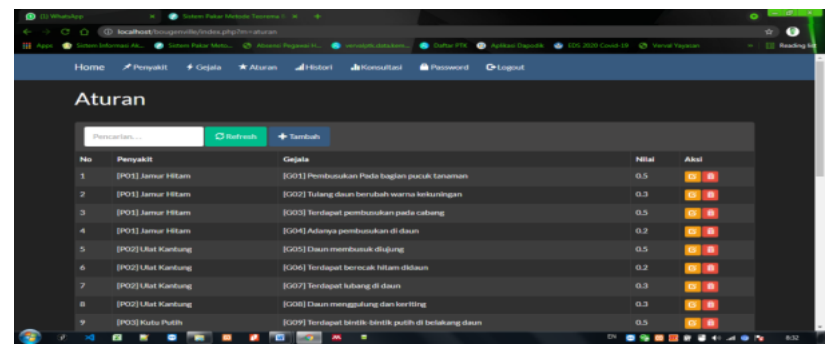

Gambar 6. Interface Form Basis Pengetahuan

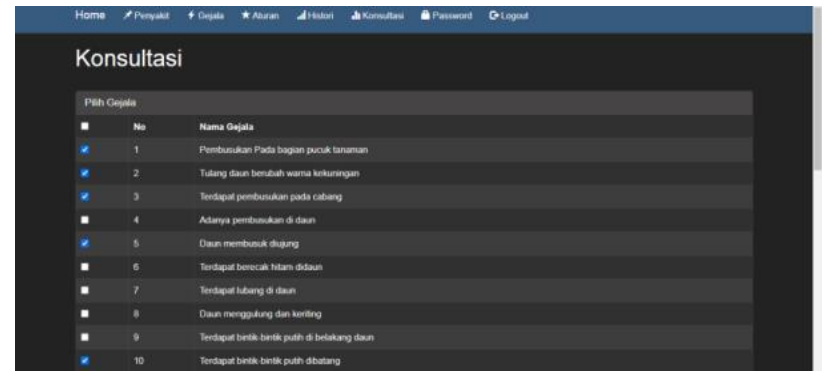

Gambar 7. Interface Form Konsultasi

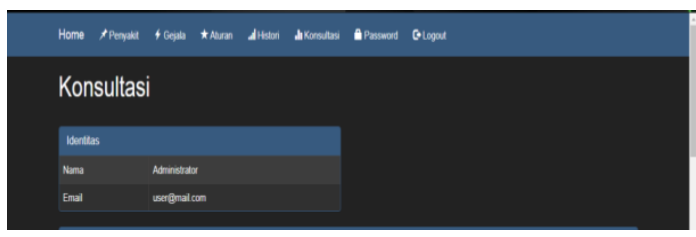




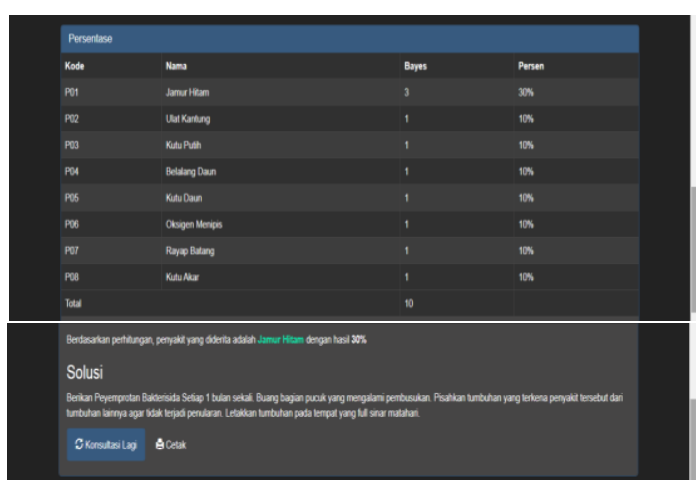

Gambar 8. Interface Form Laporan Hasil

\section{Penutup}

Berdasarkan uraian yang telah penulis lakukan tentang diangnosa penyakit Bunga Kertas dengan teorema Bayes, maka penbulis dapat menarik beberapa kesimpulan sebagai berikut:

1. Sistem Pakar yang dihasilkan pada penelitian ini merupakan hasil dari analisa pengetahuan dan keilmuan pakar yang memberikan informasi dan data tentang penyakit Bunga kertas yang diakusisi ke dalam bentuk aturan-aturan yang nantinya dapat ditelusuri dan diidentifikasi kemungkinan penyakit yang diderita Bunga kertas yang diimplementasikan kedalam sistem terkomputerisasi atau aplikasi cerdas.

2. Pembangunan Sistem Pakar didahului dengan mengumpulkan beberapa informasi dan pengetahuan ahli yang berkaitan tentang pendeteksian gejala-gejala klinis yang terdapat pada manifestasi penyakit Bunga kertas yang selanjutnya dibentuk kedalam basis atau kumpulan pengetahuan, kemudian dilakukan proses perhitungan dan penerapan dengan Teorema bayes yang memilki tujuan untuk menghasilkan tingkat kemungkinan terserang penyakit dari gejala-gejala yang teridentifikasi.

\section{Daftar Pustaka}

[1] D. Satria and T. Hidayat, "Implementation of wireless sensor network ( WSN ) on garbage transport warning information system using GSM module Implementation of wireless sensor network ( WSN ) on garbage transport warning information system using GSM module," 2019.

[2] D. Satria, S. Yana, E. Yusibani, S. Syahreza, and Zulfan, "Visualization system for water levels and environmental conditions in the flood monitoring information system," Int. J. Innov. Technol. Explor. Eng., vol. 8, no. 11, 2019.

[3] R. Noviani and S. Sulindawaty, "Sistem Pakar Mendiagnosa Gizi Buruk Pada Balita Menggunakan Teorema Bayes," J. Nas. Komputasi dan Teknol. Inf., vol. 3, no. 2, pp. 163-169, 2020.

[4] A. Arifsyah and A. Sindar, "Sistem Pakar Diagnosa Penyakit Pohon Karet Dengan Metode Certainty Factor," J. Nas. Komputasi dan Teknol. Inf., vol. 2, no. 2, pp. 175-180, 2019.

[5] F. A. Mahesa and S. Sulindawaty, "Sistem Pakar Mendiagnosa Penyakit Epilepsi Menggunakan Metode Dempster Shafer," J. Nas. Komputasi dan Teknol. Inf., vol. 4, no. 6, pp. 415-424, 2021.

[6] N. Indriyani, E. Ali, U. Rio, and R. Rahmaddeni, "Menentukan Kualitas Pelayanan Maskapai Penerbangan Domestik Dengan Menggunakan Metode Naïve Bayes," SATIN-Sains dan Teknol. Inf., vol. 6 , no. 1 , pp. 37-44, 2020. 